Article

\title{
The Complete Mitochondrial Genome of the Pink Stem Borer, Sesamia inferens, in Comparison with Four Other Noctuid Moths
}

\author{
Huan-Na Chai and Yu-Zhou Du* \\ Institute of Applied Entomology, Yangzhou University, Yangzhou 225009, China; \\ E-Mails: chaihuanna@126.com \\ * Author to whom correspondence should be addressed; E-Mail: yzdu@yzu.edu.cn; \\ Tel.: +86-514-87971854; Fax: +86-514-87971854.
}

Received: 25 May 2012; in revised form: 1 August 2012 / Accepted: 11 August 2012 / Published: 16 August 2012

\begin{abstract}
The complete 15,413-bp mitochondrial genome (mitogenome) of Sesamia inferens (Walker) (Lepidoptera: Noctuidae) was sequenced and compared with those of four other noctuid moths. All of the mitogenomes analyzed displayed similar characteristics with respect to gene content, genome organization, nucleotide comparison, and codon usages. Twelve-one protein-coding genes (PCGs) utilized the standard ATN, but the cox1 gene used CGA as the initiation codon; cox1, cox2, and nad4 genes had the truncated termination codon $\mathrm{T}$ in the $S$. inferens mitogenome. All of the tRNA genes had typical cloverleaf secondary structures except for $\operatorname{trnS1}(A G N)$, in which the dihydrouridine (DHU) arm did not form a stable stem-loop structure. Both the secondary structures of $r r n L$ and $r r n S$ genes inferred from the $S$. inferens mitogenome closely resembled those of other noctuid moths. In the A+T-rich region, the conserved motif "ATAGA" followed by a long T-stretch was observed in all noctuid moths, but other specific tandem-repeat elements were more variable. Additionally, the $S$. inferens mitogenome contained a potential stem-loop structure, a duplicated 17-bp repeat element, a decuplicated segment, and a microsatellite "(AT) 7 ", without a poly-A element upstream of the trnM in the A+T-rich region. Finally, the phylogenetic relationships were reconstructed based on amino acid sequences of mitochondrial 13 PCGs, which support the traditional morphologically based view of relationships within the Noctuidae.
\end{abstract}

Keywords: Sesamia inferens; mitochondrial genome; lepidoptera; Noctuidae; phylogenetic relationship 


\section{Introduction}

The pink stem borer, Sesamia inferens (Walker), is an important rice pest that is widely distributed in China, Japan, India and other countries, and causes severe damage to rice crops in rice planting areas [1-3]. Since 1990, with the expansion of hybrid rice planting areas and changes in climate and rice cultivation systems, the $S$. inferens population has been gradually increasing in China, and has become an important rice pest next to Chilo suppressalis (Walker), especially in the Lower-Middle Reaches of the Yangze River [3]. At present, the mitochondrial genomes (mitogenomes) from more than 393 species of arthropods have been completely or partially determined, including 241 species of insects. However, only 36 mitogenomes from six lepidopteran superfamilies have been sequenced, with seven species of Bombycoidea, one species of Geometroidea, 14 species of Papilionoidea, six species of Pyraloidea, three species of Tortricoidea, and five species of Noctuoidea, including Helicoverpa armigera, Hyphantria cunea, Lymantria dispar, Ochrogaster lunifer, and S. inferens [4-7].

The insect mitogenome is normally a closed-circular duplex molecule, ranging from 14 to $20 \mathrm{~kb}$ in length. The mitogenome usually contains 13 protein-coding genes (PCGs: atp6, atp8, cox1, cox2, cox3, cob, nad1, nad2, nad3, nad4, nad5, nad6, and nad4L), large and small ribosomal RNA genes ( $r r n L$ and rrnS), 22 tRNA genes, which are involved in energy production, electron transport and oxidative phosphorylation [8,9]. In addition, at least one segment of the most variable A+T-rich region is present in the insect mitogenome, including initiation sites for the transcription and replication of the genome [10,11].

Compared with the nuclear genome, the animal mitogenome - except for lice [12] — usually has a smaller size, a stable and relatively short circular structure. In addition, it has other characteristics such as a higher rate of base substitution and a presumed lack of intermolecular recombination. Mitogenome has been widely used as an informative molecular marker to reveal fundamental information for phylogenetic inference, the identification of species, phylogeography, the analysis of population structure and dynamics, and molecular evolution at the genomic level. This has been especially true for the past several decades, especially since the human mitogenome was sequenced [13]. More and more insect mitogenomes will increase the richness of information for phylogenetic analyses and evolutionary biology.

In this study, we report the completed mitogenome of $S$. inferens and provide a thorough description of its genomic features, including gene order, nucleotide composition of PCGs, secondary structures of tRNA and rRNA genes, and A+T-rich region. In addition, we compare the $S$. inferens mitogenome with those of four other noctuid moths, which can provide further insights into the relationships among Noctuidae species. Detailed genetic information on this important rice pest may help in the development of methods for its control or prevention.

\section{Results and Discussion}

\subsection{Genome Structure, Organization and Composition}

The complete mitogenome of S. inferens was found to be a 15,413 bp long circular molecule, and its sequence was deposited into GenBank (Accession number: JN039362) (Figure 1 and Table 1). The size was shorter than that of $H$. cunea (15,481 bp), L. dispar (15,569 bp), and O. lunifer $(15,593 \mathrm{bp})[4,5,7]$. 
All of the 37 typical animal mitochondrial genes (13 PCGs, 22 tRNA and 2 rRNA genes) were present, and the gene order was the same as in other sequenced noctuid moths, in an order of trnM, trnI, and trnQ. The position of the trnM gene was usually translocated to the $5^{\prime}$ upstream position of trnI in the lepidopteran species, which was different from those of other order species [14]. This indicated that the mitochondrial gene arrangement in lepidopteran species evolved independently after splitting from its stem lineage [15]. In addition, a total of $257 \mathrm{bp}$ of intergenic spacer sequences were present in 18 locations with the exception of the A+T-rich region, and a total of $25 \mathrm{bp}$ of overlapping nucleotides was scattered over six locations in the S. inferens mitogenome.

Figure 1. A map of the mitogenome of Sesamia inferens. Transfer RNA genes are designated by single-letter amino acid codes. $\mathrm{CR}$ represents the $\mathrm{A}+\mathrm{T}$-rich region. The gene name without underline indicates the direction of transcription from left to right, and with underline indicates right to left. s1-s4, intergenic spacers.

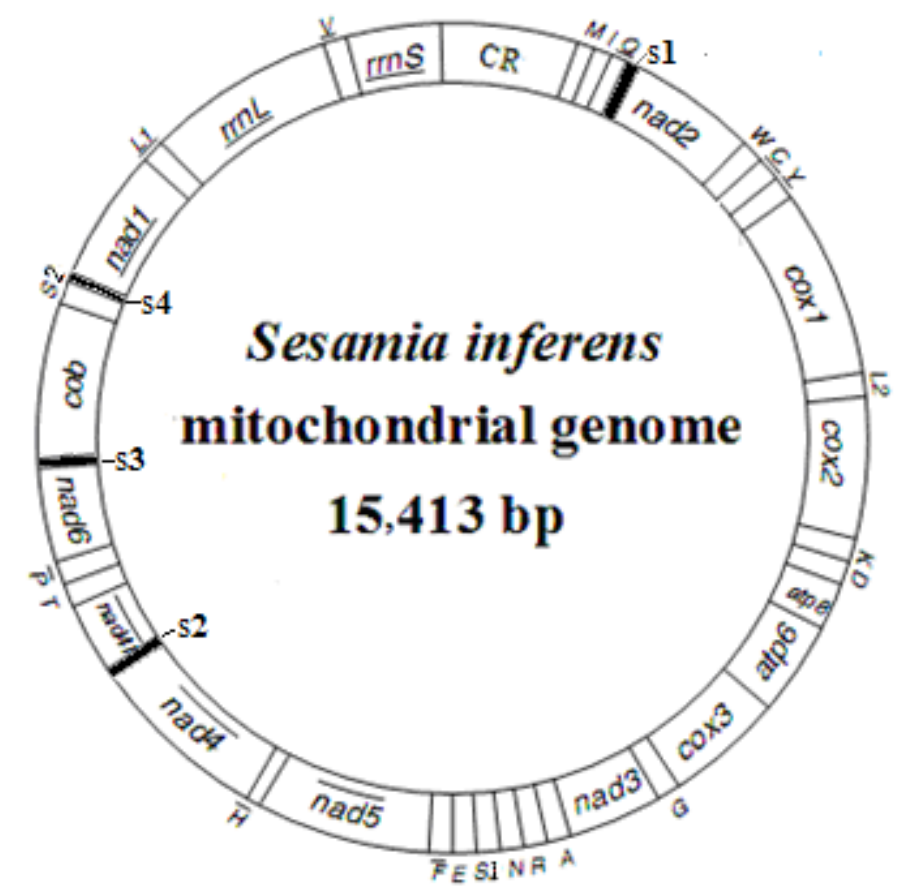

Table 1. Annotation of the mitogenome of Sesamia inferens.

\begin{tabular}{|c|c|c|c|c|c|c|c|}
\hline Name & Direction & Site & Size (bp) & $\begin{array}{c}\text { Intergenic } \\
\text { spacer }\end{array}$ & Anticodon & $\begin{array}{l}\text { Start } \\
\text { codon }\end{array}$ & $\begin{array}{l}\text { Stop } \\
\text { codon }\end{array}$ \\
\hline $\operatorname{trn} M$ & $\mathrm{~F}$ & $1 . .68$ & 68 & 0 & 32..34 CAT & & \\
\hline $\operatorname{trnI}$ & $\mathrm{F}$ & $69 . .133$ & 65 & -3 & 98..100 GAT & & \\
\hline $\operatorname{trn} Q$ & $\mathrm{R}$ & $131 . .199$ & 69 & 68 & 167..169 TTG & & \\
\hline nad2 & $\mathrm{F}$ & $268 . .1284$ & 1017 & 6 & & ATT & TAA \\
\hline $\operatorname{trn} W$ & $\mathrm{~F}$ & $1291 . .1358$ & 68 & -8 & $1322 . .1324$ TCA & & \\
\hline $\operatorname{trn} C$ & $\mathrm{R}$ & $1351 . .1423$ & 73 & 4 & 1391..1393 GCA & & \\
\hline $\operatorname{trn} Y$ & $\mathrm{R}$ & $1428 . .1494$ & 67 & 5 & $1460 . .1462$ GTA & & \\
\hline $\operatorname{cox} 1$ & $\mathrm{~F}$ & $1500 . .3030$ & 1531 & 3 & & CGA & $\mathrm{T}-$ \\
\hline $\operatorname{trnL2(UUR)}$ & $\mathrm{F}$ & $3034 . .3100$ & 67 & 0 & 3064..3066 TAA & & \\
\hline $\operatorname{cox} 2$ & $\mathrm{~F}$ & $3101 . .3782$ & 682 & 0 & & ATT & T- \\
\hline
\end{tabular}


Table 1. Cont.

\begin{tabular}{|c|c|c|c|c|c|c|c|}
\hline Name & Direction & Site & Size (bp) & $\begin{array}{c}\text { Intergenic } \\
\text { spacer }\end{array}$ & Anticodon & $\begin{array}{c}\text { Start } \\
\text { codon }\end{array}$ & $\begin{array}{c}\text { Stop } \\
\text { codon }\end{array}$ \\
\hline $\operatorname{trnK}$ & $\mathrm{F}$ & $3783 . .3853$ & 71 & 0 & $3813 . .3815$ CTT & & \\
\hline $\operatorname{trn} D$ & $\mathrm{~F}$ & $3854 . .3919$ & 66 & 0 & 3884..3886 GTC & & \\
\hline atp8 & $\mathrm{F}$ & $3920 . .4087$ & 168 & -11 & & ATT & TAA \\
\hline atp6 & $\mathrm{F}$ & $4077 . .4754$ & 696 & -1 & & ATG & TAA \\
\hline $\operatorname{cox} 3$ & $\mathrm{~F}$ & $4754 . .5542$ & 789 & 2 & & ATG & TAA \\
\hline $\operatorname{trn} G$ & $\mathrm{~F}$ & $5545 . .5609$ & 65 & 0 & 5575..5577 ТCC & & \\
\hline nad3 & $\mathrm{F}$ & $5610 . .5963$ & 354 & 16 & & ATT & TAA \\
\hline $\operatorname{trn} A^{\prime}$ & $\mathrm{F}$ & $5980 . .6048$ & 69 & 2 & 6010..6012 TGC & & \\
\hline $\operatorname{trnR}$ & $\mathrm{F}$ & $6051 . .6114$ & 64 & 9 & $6078 . .6080 \mathrm{TCG}$ & & \\
\hline $\operatorname{trnN}$ & $\mathrm{F}$ & $6124 . .6188$ & 65 & 2 & 6154..6156 GTT & & \\
\hline $\operatorname{trnS1}(A G N)$ & $\mathrm{F}$ & $6191 . .6256$ & 66 & 0 & 6216..6218 GCT & & \\
\hline $\operatorname{trnE}$ & $\mathrm{F}$ & $6257 . .6324$ & 68 & 8 & 6287..6289 ТTC & & \\
\hline $\operatorname{trnF}$ & $\mathrm{R}$ & 6333..6399 & 67 & -1 & 6364..6366 GAA & & \\
\hline nad5 & $\mathrm{R}$ & $6399 . .8150$ & 1752 & 0 & & ATT & TAA \\
\hline $\operatorname{trnH}$ & $\mathrm{R}$ & $8151 . .8215$ & 65 & 0 & $8183 . .8185$ GTG & & \\
\hline nad4 & $\mathrm{R}$ & $8216 . .9554$ & 1339 & 44 & & ATG & $\mathrm{T}-$ \\
\hline nad4L & $\mathrm{R}$ & $9599 . .9892$ & 294 & 7 & & ATG & TAA \\
\hline $\operatorname{trnT}$ & $\mathrm{F}$ & $9900 . .9969$ & 70 & 0 & 9929..9931 TGT & & \\
\hline $\operatorname{trn} P$ & $\mathrm{R}$ & $9970 . .10034$ & 65 & 7 & $10002 . .10004$ TGG & & \\
\hline nad6 & $\mathrm{F}$ & $10042 . .10575$ & 534 & 44 & & ATC & TAA \\
\hline$c o b$ & $\mathrm{~F}$ & $10620 . .11768$ & 1149 & 1 & & ATG & TAA \\
\hline $\operatorname{trnS2}(U C N)$ & $\mathrm{F}$ & $11770 . .11836$ & 67 & 18 & 11802..11804 TGA & & \\
\hline nad1 & $\mathrm{R}$ & $11855 . .12799$ & 945 & 1 & & ATG & TAA \\
\hline $\operatorname{trnL1}(C U N)$ & $\mathrm{R}$ & $12801 . .12867$ & 67 & -1 & $12836 . .12838 \mathrm{TAG}$ & & \\
\hline$r r n L$ & $\mathrm{R}$ & $12867 . .14251$ & 1385 & 0 & - & & \\
\hline $\operatorname{trn} V$ & $\mathrm{R}$ & $14253 . .14318$ & 66 & 0 & $14284 . .14286$ TAC & & \\
\hline$r r n S$ & $\mathrm{R}$ & $14319 . .15102$ & 784 & 0 & & & \\
\hline A+T-rich region & & $15103 . .15413$ & 311 & 0 & & & \\
\hline
\end{tabular}

* Negative numbers indicate that adjacent genes overlap.

Table 2. Skewed nucleotide composition in regions of noctuid moths' mitogenomes.

\begin{tabular}{|c|c|c|c|c|c|c|c|}
\hline \multirow[b]{2}{*}{ Species } & \multicolumn{2}{|c|}{ Whole mitogenome } & \multicolumn{5}{|c|}{ PCGs } \\
\hline & $\begin{array}{c}\text { Length } \\
\text { (bp) }\end{array}$ & $\begin{array}{l}\text { AT } \\
(\%)\end{array}$ & $\begin{array}{c}\text { Length } \\
\text { (bp) }\end{array}$ & $\begin{array}{l}\text { AT } \\
(\%)\end{array}$ & $\begin{array}{c}\text { 1st position } \\
(\%)\end{array}$ & $\begin{array}{c}\text { 2nd position } \\
\text { (\%) }\end{array}$ & $\begin{array}{c}\text { 3rd position } \\
(\%)\end{array}$ \\
\hline H. armigera & 15347 & 81.0 & 11,133 & 79.4 & 70.2 & 94.1 & 73.8 \\
\hline H. cunea & 15481 & 80.4 & 11,136 & 78.5 & 73.2 & 70.3 & 92.0 \\
\hline L. dispar & 15569 & 79.9 & 11,169 & 77.7 & 90.2 & 72.9 & 70.1 \\
\hline O. lunifer & 15593 & 77.8 & 11,196 & 75.7 & 72.0 & 70.0 & 85.1 \\
\hline S. inferens & 15413 & 80.3 & 11,160 & 78.6 & 87.7 & 72.9 & 75.2 \\
\hline
\end{tabular}

The nucleotide composition of the $S$. inferens mitogenome was also biased toward AT nucleotides (80.3\%), which was slightly higher than those of L. dispar $(79.9 \%)$ and O. lunifer $(77.8 \%)$, but was slightly lower than those of H. armigera (81.0\%) and H. cunea (80.4\%) [4-7] (Table 2). The AT skew in the $S$. inferens mitogenome was slightly negative $(-0.001)$, indicating the occurrence of more Ts than As. This value was different from those of other Noctuidae species, such as H. armigera (0.002), 
H. cunea (0.010), L. dispar (0.016), O. lunifer (0.030) [4-7]. Meanwhile, the GC skew in the $S$. inferens mitogenome was negative $(-0.228)$, demonstrating the occurrence of more Cs than Gs. This was also true for H. armigera (-0.184), H. cunea (-0.230), L. dispar (-0.247), O. lunifer (-0.318) [4-7].

\subsection{Protein-Coding Genes}

The mitochondrial sequence of S. inferens, as in most insects, contained 13 PCGs (Table 2). Most of the PCGs utilized typical ATN start codons (ATG, ATT, and ATC), among which six genes started with codon ATG (atp6, cox3, nad4, nad4L, cob, and nad1), five with ATT (nad2, cox2, atp8, nad3, and nad5), and the nad6 gene with ATC. However, the cox1 gene in the S. inferens mitogenome had the start codon CGA as observed in most other lepidopteran species sequenced to date [16]. Notably, the start codon of the cox 1 gene is usually found to use nonstandard putative codons, as previously reported in arthropod species [17-20].

The conventional termination codon TAA, likely resulting from post-transcriptional polyadenylation [21], was observed in 10 PCGs. However, the cox1, cox2, and nad4 genes utilized truncated termination codons, which are commonly observed in lepidopteran species.

Figure 2. Codon distributions in five noctuid moths' mitogenomes as indicated. The total number of codons per thousand codons (designated as CDsp T) is shown on the $y$-axis and the codon families on the $x$-axis.

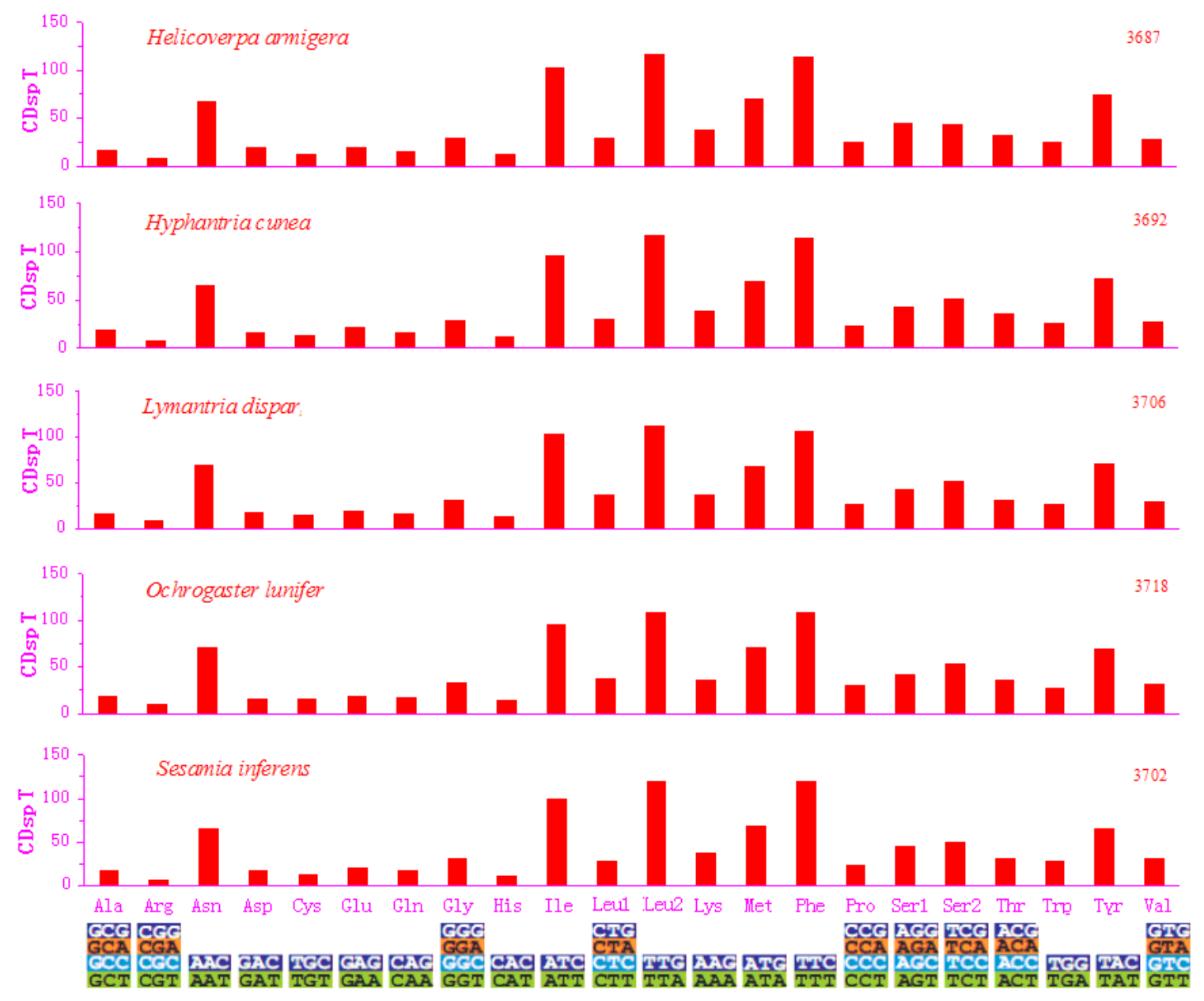


The average AT content of the 13 PCGs in the $S$. inferens mitogenome was $78.6 \%$, with a negative AT skew of -0.148 and a slightly positive GC skew of 0.037 (Table 2). The AT and GC skews were similar to those of H. armigera $(-0.139,0.029)$, H. cunea $(-0.146,0.023)$, and L. dispar $(-0.148,0.013)$, indicating that the contents of $\mathrm{T}$ and $\mathrm{G}$ were higher than those of $\mathrm{A}$ and $\mathrm{C}$, respectively [5-7]. It is to be noted that both the AT skew $(-0.141)$ and the GC skew $(-0.004)$ were slightly negative in the 13 PCGs of O. lunifer [4]. Also, the AT contents at different codon positions was analyzed. In the S. inferens mitogenome, the AT contents was $87.7 \%, 72.9 \%$ and $75.2 \%$ at the first, second and third codon positions, respectively, with the highest AT contents at the first codon position, which was similar to the result from $L$. dispar mitogenome $(90.2 \%, 72.9 \%, 70.1 \%)$, but was different from that in H. armigera $(70.2 \%, 94.1 \%, 73.8 \%), H$. cunea $(73.2 \%, 70.3 \%, 92.0 \%)$ and O. lunifer mitogenomes $(72.0 \%, 70.0 \%, 85.1 \%)[4-7]$ (Table 2).

Figure 3. The relative synonymous codon usage (RSCU) in five noctuid moths' mitogenomes as a function of codon families. Red codons indicate that the codons are missing in the mitogenome.
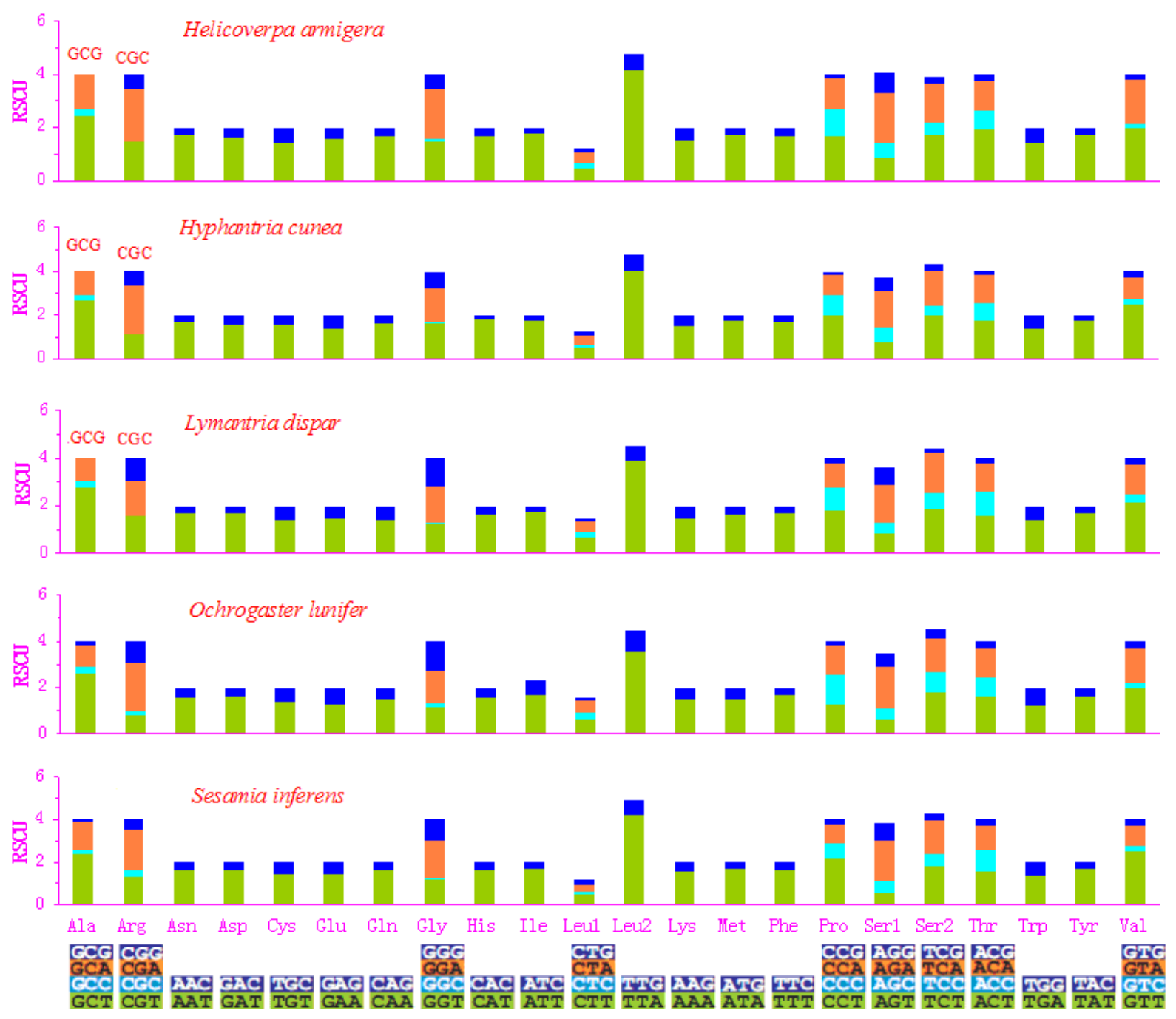

Excluding the start and termination codons, the 13 PCGs in the S. inferens mitogenome consisted of 3702 codons in total, consistent with the observations in four other noctuid moths, which ranged from 
3687 in the H. armigera to 3718 codons in the O. lunifer mitogenome [4-7] (Figure 2). The codon families exhibited a very similar behavior among the five species (Figures 2 and 3). There were at least six codon families with at least 50 codons (CDs) (Asn, Ile, Leu2, Met, Phe, Tyr), and two families with at least $100 \mathrm{CDs}$ per thousand CDs (Leu2 and Phe) as observed in five insects. In addition, the AT-rich CDs favor synonymous CDs with a lower AT content, as revealed by the Relative Synonymous Codon Usage (RSCU) results, and exemplified by the Leu2 family, in which the TTA codon accounted for the large majority of CDs (Figure 3). The codon families with high CDs had A and T predominantly in the third position, which might reflect selection for optimal tRNA usage, genome bias, and the speed and efficacy of genome/DNA repair [22].

\subsection{Transfer RNA Genes}

The mitogenome of $S$. inferens had the characteristic 22 tRNAs sets interspersed by rRNAs or PCGs, with an AT content of $81.5 \%$ and a total of $1478 \mathrm{bp}$ in size ranging from 64 to $73 \mathrm{bp} / \mathrm{tRNA}$. All tRNA genes had the typical cloverleaf secondary structures except for the $\operatorname{trnS1}(A G N)$ gene, in which a stable stem-loop structure of the dihydrouridine (DHU) arm was missing (Figure 4), as observed in many metazoan mitogenomes [23-25]. Eight tRNAs were encoded by the L-strand and the remaining 14 by the H-strand, which was identical in all the species. All tRNA genes usually contained a 7-bp amino acid acceptor (AA) stem, where most nucleotide substitutions were compensatory. The anticodon (AC) stem and the loop ( $7 \mathrm{bp}$ ) were both conserved in all tRNAs, whereas two U-U pairs were usually located at the second and third couplets in the anticodon stem of trnS2(UCN). The length of DHU was 3-4 bp, except for trnS1(AGN). The TYC arm was usually 3-6 bp in length. Except for trnD, trnE, and trnY, a total of 29 unmatched base pairs were detected in the $S$. inferens tRNAs, but 18 of them were G-U pairs, which form a weak bond in the tRNAs, and are well-known non-canonical pairs in tRNA secondary structures [26]. The remaining 11 were mismatched base pairs including seven $U-U$, one C-U, and three A-C pairs. Notably, the numbers of mismatches varied in different noctuid moths, with 4, 7, 23 and 10 mismatches in H. armigera, H. cunea, L. dispar, and O. lunifer, respectively [4-7].

Figure 4. Inferred secondary structures for 22 typical tRNAs of the Sesamia inferens mitogenome. The tRNAs are labeled with the abbreviations of their corresponding amino acids. Base-pairing is indicated as follows: Watson-Crick pairs by lines, wobble GU pairs by dots and mismatched pairs by circles.

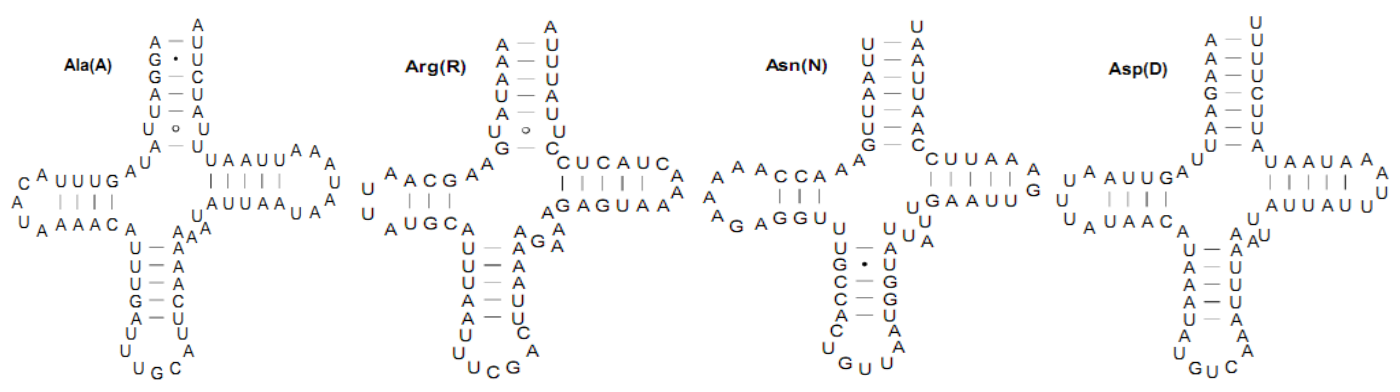


Figure 4. Cont.

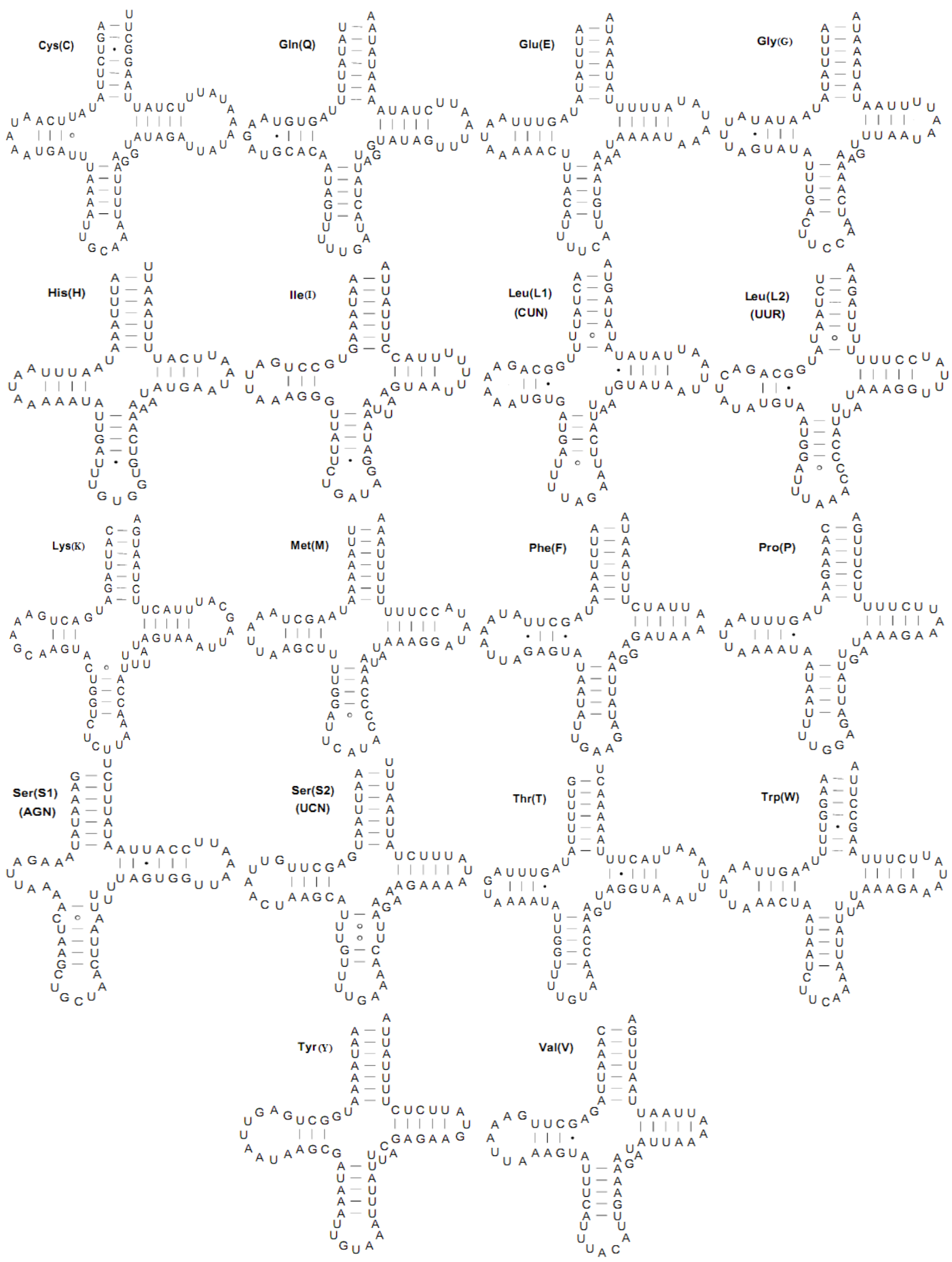

\subsection{Ribosomal RNA Genes}

As in other mitochondrial sequences from Insecta species, there were two rRNAs in S. inferens with a total length of $2169 \mathrm{bp}$ and an AT content of $84.1 \%$. The large ribosomal gene ( $r r n L)$ had a length of $1385 \mathrm{bp}$, located between $\operatorname{trnL1}(C U N)$ and $\operatorname{trnV}$, whereas the small one ( $r r n S)$ had a length of $784 \mathrm{bp}$ between trnV and the A+T-rich region. The gene sizes and locations were typical as in other noctuid moths' mitogenomes. Both tRNA and rRNA genes of Noctuidae species predominantly contained A and 
T [4-7] (Table 2). Furthermore, both the AT and GC skews were slightly positive in the tRNA and rRNA genes, consistent with the results in $H$. armigera and $H$. cunea mitogenomes [5,6].

Figure 5. The predicted $r r n L$ secondary structure from the Sesamia inferens mitogenome. The $5^{\prime}$ half of $r r n L$ is displayed in $\mathbf{A}$ and the remaining $3^{\prime}$ half in $\mathbf{B}$. Base-pairings are indicated as follows: Watson-Crick pairs by lines, wobble GU pairs by dots and mismatched pairs by circles.

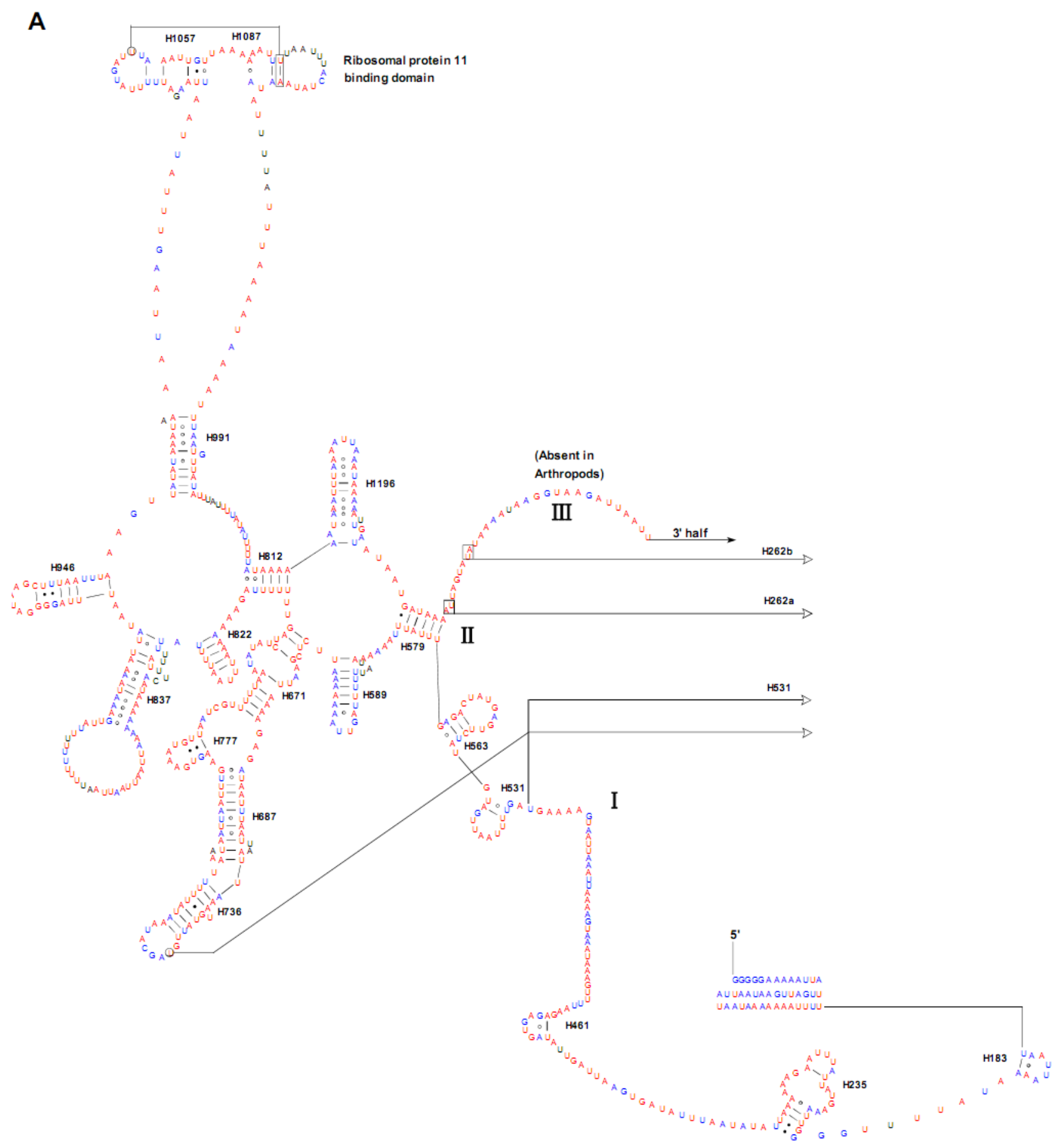


Figure 5. Cont.

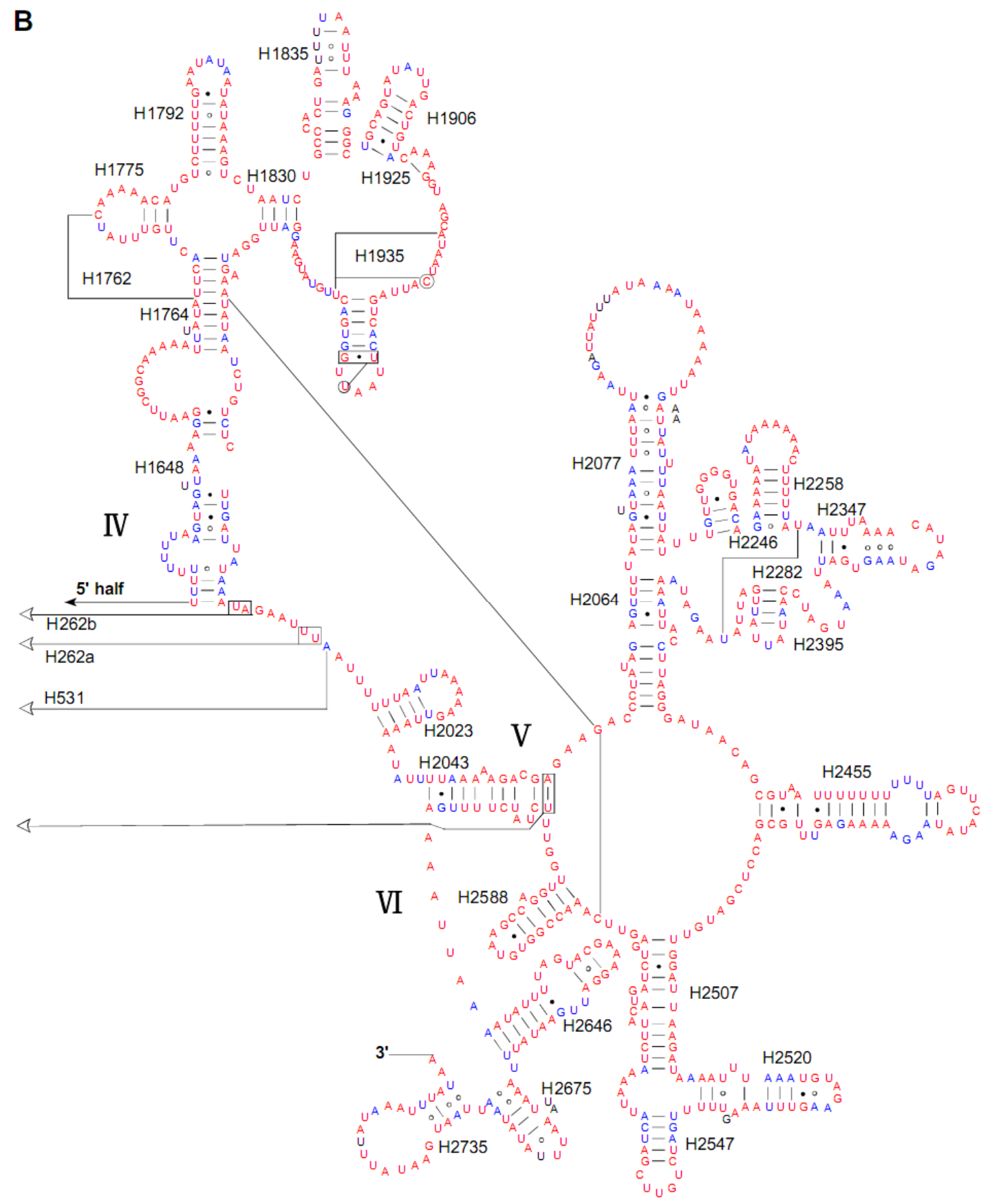

Both the $r r n L$ and $r r n S$ secondary structures were predicted according to models proposed for these genes in other insects [27,28]. Although the length of individual helices varied in insect species, the secondary structures of both $r r n L$ and $r r n S$ in $S$. inferens were quite similar to their counterparts in Apis mellifera, Manduca sexta, and other insect species [27,28]. In S. inferens, the rrnL gene contained five domains (labeled I, II, IV, V, and VI) with 49 helices, as observed in other noctuid moths (Figure 5). Each domain was separated by a single-stranded region, and domain III was absent in arthropod mitogenomes. Also, S. inferens had the rrnS with 33 helices in three domains (labeled I, II, III) (Figure 6). 
Figure 6. The predicted rrnS secondary structure in the Sesamia inferens mitogenome. Tertiary interactions and base triples are shown connected by continuous lines. Base-pairings are indicated in Figure 5.

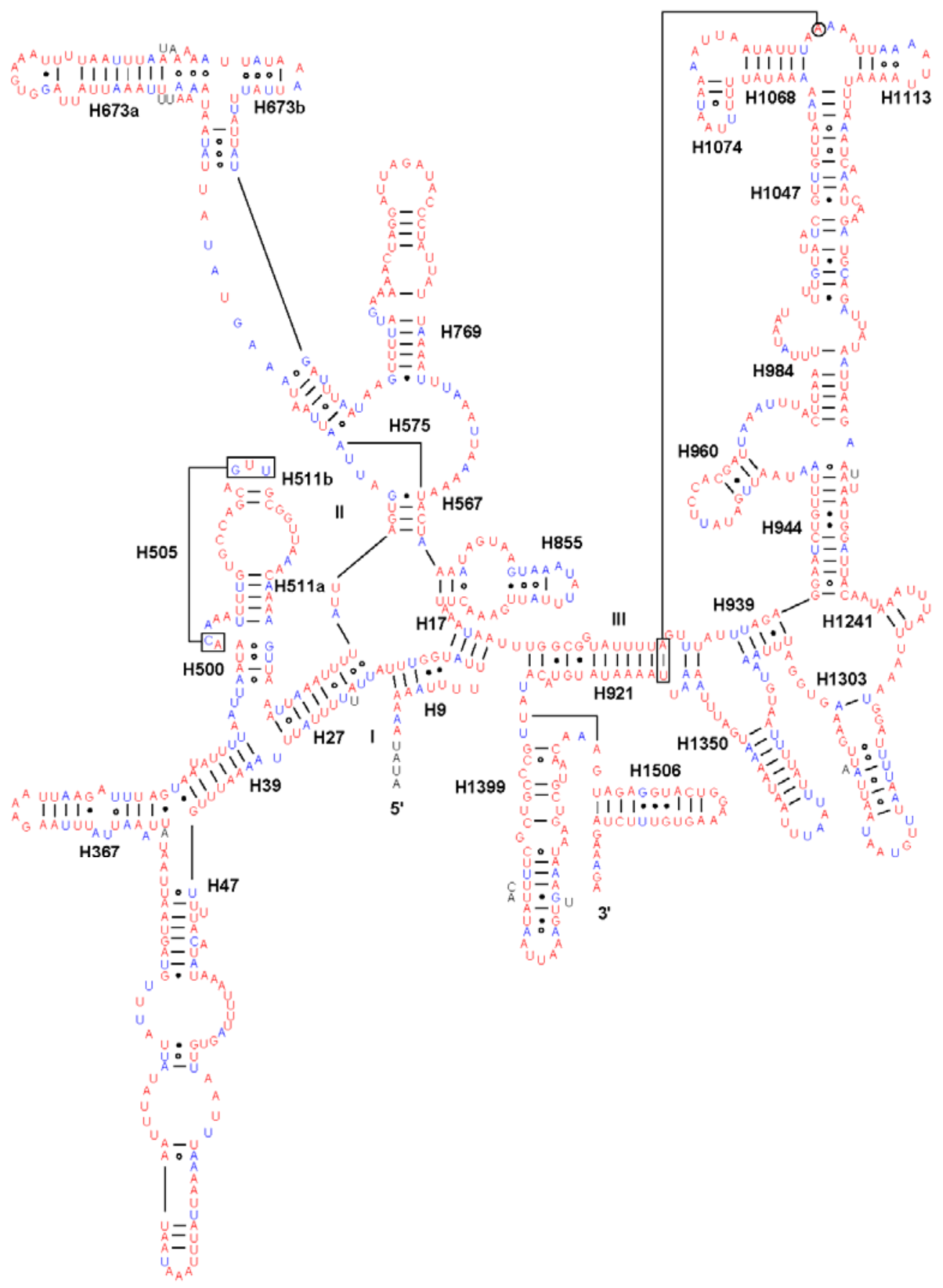

\subsection{Non-Coding and Overlapping Regions}

In the $S$. inferens mitogenome, there was a total of $257 \mathrm{bp}$ of intergenic spacer sequences, which resided at 18 locations (except for the A+T-rich region) and varied in size from 1 to $68 \mathrm{bp}$. It is to be noted that there were four major intergenic spacers (s1-s4) spanning at least $18 \mathrm{bp}$, all of which were rich in As and Ts (Figure 7). The s1 spacer (68 bp) located between trnQ and nad2 had a higher AT content compared with the counterpart in the O. lunifer mitogenome. And so did the other three spacers. 
The s3 spacer (44 bp), inserted between nad6 and cob, is not conserved in five noctuid moths, which was mostly a 4 bp repeat in the $S$. inferens mitogenome while the other had a stretch of TA dinucleotides in the $L$. dispar mitogenome. However, the s2 spacer (44 bp), placed between nad4 and nad4L, was longer than its counterparts in $H$. armigera and L. dispar mitogenomes, but it was twice the length of the counterpart in the L. dispar mitogenome ( 44 vs. 22 ) and about the same size as the counterpart in the H. armigera mitogenome (44 vs. 43). In addition, the s4 spacer (18 bp), located between trnS2(UCN) and nad1, did not contain the motif "ATACTAA" that was conserved across four other noctuid moths and other lepidopteran species mitogenomes [28,29].

Figure 7. Intergenic spacer sequences in the mitogenomes of Sesamia inferens and other noctuid moths.
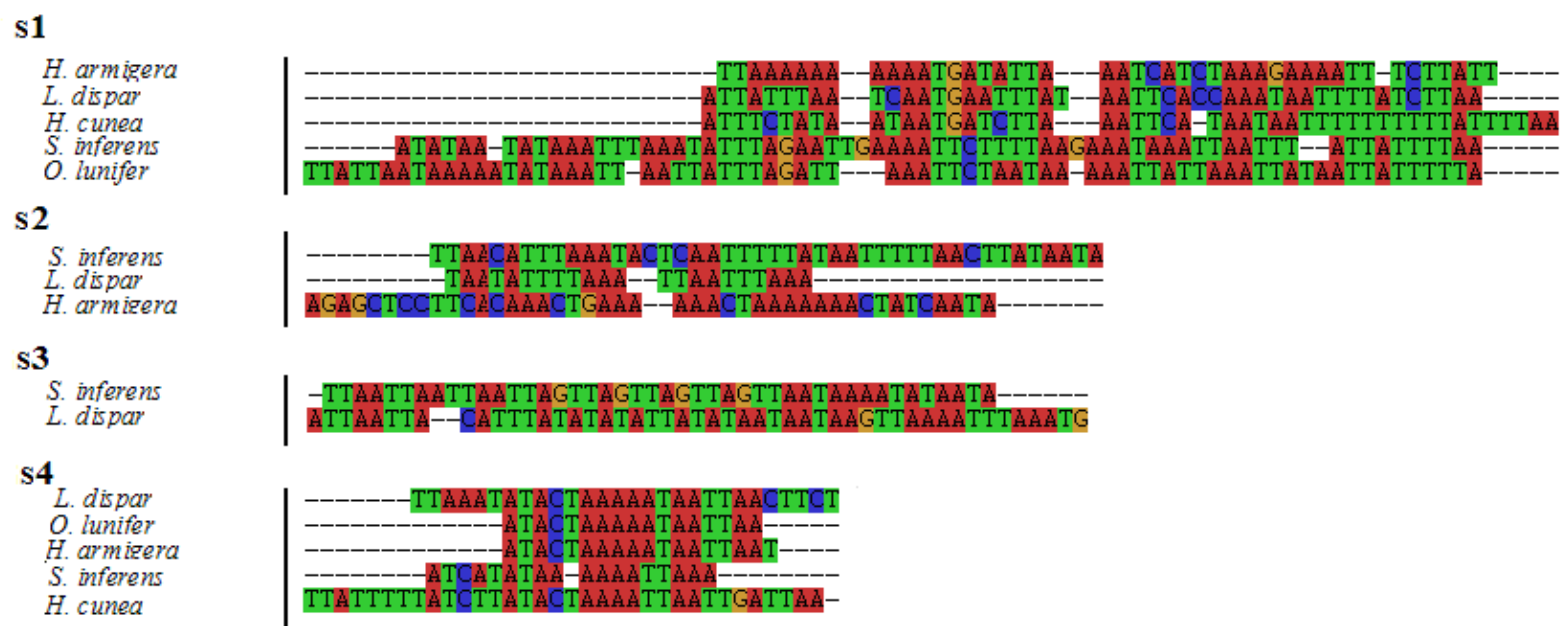

Also, a total of $25 \mathrm{bp}$ overlapping nucleotides was scattered over six locations and ranged in sizes from 1 to $11 \mathrm{bp}$ in the $S$. inferens mitogenome, with the longest one (11 bp) located between atp8 and atp6. Interestingly, an 8-bp motif "AAGCCTTA" conserved in the four other noctuid moths" mitogenomes [4-7] was also detected between $\operatorname{trn} W$ and $\operatorname{trn} C$ in the present study.

\subsection{A+T-rich Region}

In mitochondrial genomes, the $\mathrm{A}+\mathrm{T}$-rich region had been reported to possess essential elements involved in the initiation of replication and transcription of mitogenome [30]. The A+T-rich region of the $S$. inferens mitogenome was $311 \mathrm{bp}$ in length with an AT content of 95.8\%. Similarly, the sizes and AT contents in the A+T-rich regions of four other noctuid moths were $328 \mathrm{bp}$ and $95.1 \%$ AT content (H. armigera), 357 bp and 95.0\% AT content (H. cunea), 369 bp and 96.1\% AT content (L. dispar), and $319 \mathrm{bp}$ and $93.4 \%$ AT content (O. lunifer) [4-7]. Notably, the S. inferens A+T-rich region displayed a higher AT content (95.8\%) than all the other locations in the mitogenome (Table 2).

There was a conserved structure that combined the motif "ATAGA" and a 19-bp poly-T stretch in S. inferens A+T-rich region (Figure 8). A very similar pattern occurred in four other noctuid moths, and it was widely conserved in lepidopteran mitogenomes and might be the origin of light-strand replication [4-7,30]. There was also a stem-and-loop structure in S. inferens A+T-rich region containing a 5' flanking "TATA" and 3' flanking "G(A) $)_{n}$ " sequence, which were considered to be the site of initiation of secondary strand synthesis [31,32] (Figures 8 and 9). The stem-and loop structure might be 
the characteristic of insect mitogenomes, and it had been found in several insect orders including Orthoptera, Lepidoptera, Diptera, Plecoptera, and Hymenoptera, but it was not observed in four other noctuid moths [30,33-36]. Also, the conserved 3' flanking " $\mathrm{G}(\mathrm{A})_{n} \mathrm{~T}$ " sequence might not be present in all insects or the sequence might take on different forms [35,37].

Figure 8. The structure of the A+T-rich region of the Sesamia inferens mitogenome. The origin of light strand replication, the potential stem loop structure, the duplicated 17-bp repeat element, the decuplicated $8 \mathrm{bp}$ segment (derived from a consensus sequence "ATATTAAT") and the microsatellite "(AT) $)$ " elements are displayed as indicated in the figure.

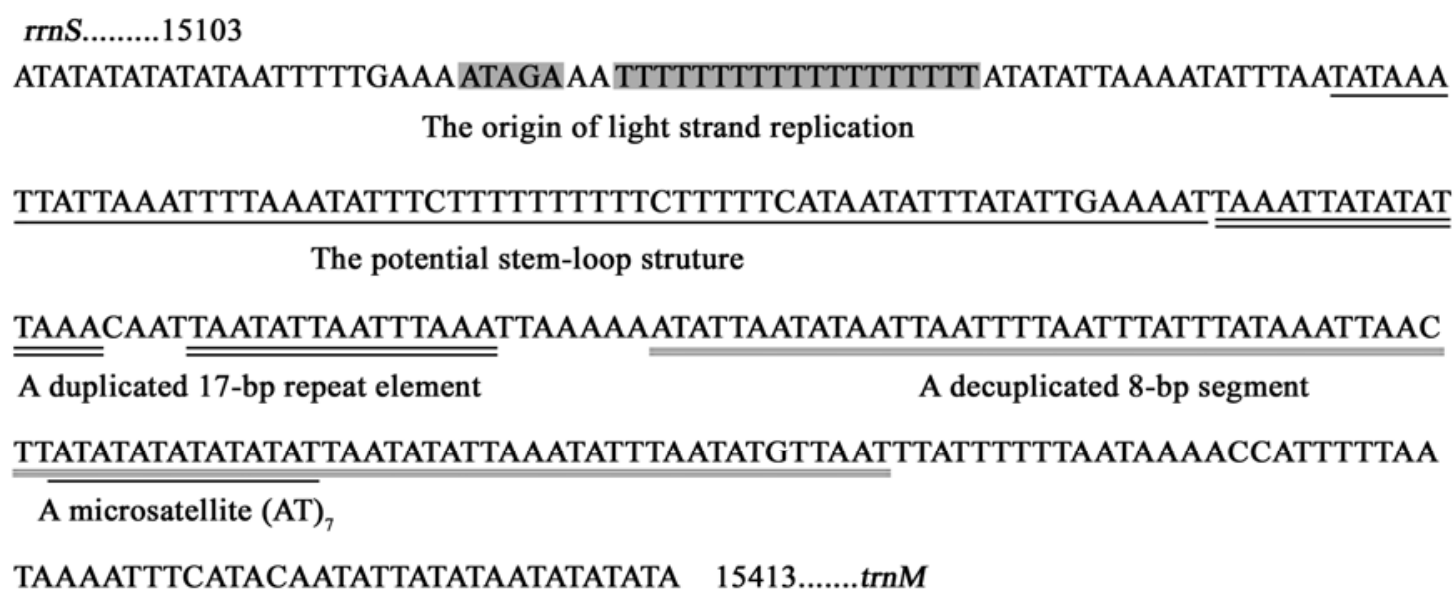

Figure 9. The potential stem-loop structure found in the Sesamia inferens A+T-rich region. The motifs ("GAAAAT" and "TATA") in the flanking region of the stem-loop structures are indicated by boxing [32].

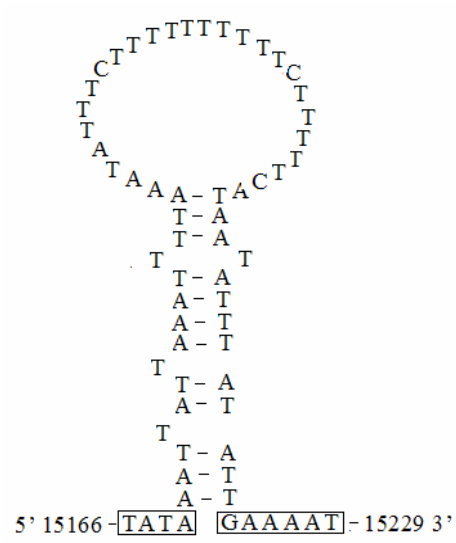

The presence of varying copy numbers of tandemly repeated elements was one of the characteristics in insect mitogenomes [30]. The S. inferens A+T-rich region contained a duplicated 17-bp repeat element with minor variations, and a decuplicated highly divergent 8-bp segment "ATATTAAT" (Figure 8), which resembled the octuplicated 8-bp repeat element "TATATATT" in the L. dispar $\mathrm{A}+\mathrm{T}$-rich region [7]. Additionally, there was a microsatellite "(AT)" in $S$. inferens $\mathrm{A}+\mathrm{T}$-rich region (Figure 8), and similar patterns were observed in $H$. cunea "(AT) 8 " and O. lunifer "(AT) $)_{7}$ " mitogenomes $[4,5]$. 
A conserved 9-bp poly-A element was observed upstream of trnM in H. cunea, L. dispar, and $O$. lunifer mitogenomes, which might be involved in controlling transcription and replication initiation $[4,5,7,38]$. However, this structure was not detected in S. inferens and $H$. armigera mitogenomes [6].

\subsection{Phylogenetic Relationships}

In this study, the amino acid sequences of the 13 PCGs were concatenated, rather than analyzed separately, to construct the phylogenetic relationships, which may result in a more complete analysis [39]. Based on morphological and genomic analyses, the relationship among six superfamilies in lepidopteran species has been reported in other articles [29,40,41].

In the present study, the NJ and MP trees showed similar topologies except for some node confidence values (Figure 10). The $S$. inferens mitogenome together with mitogenomes of $H$. armigera, $H$. cunea, L. dispar, and O. lunifer clustered with other superfamilies, which was consistent with the morphological classification [40]. Geometroidea (Phthonandria atrilineata) was closely related to Noctuoidea and Bombycoidea (Bombyx mandarina, Bombyx mori, Eriogyna pyretorum, M. sexta) [28,42-44], but Papilionoidea (Calinaga davidis and Coreana raphaelis) $[15,45]$ was the sister to Pyraloidea (C. suppressalis and Ostrinia furnacalis) [29,46], Tortricoidea (Adoxophyes honmai and Grapholita molesta) [16,38] and other superfamilies, in disagreement with the tree topology [29,40,41]. The results indicated that more mitogenomes could elaborate on phylogenetic relationships among lepidopteran superfamilies in greater detail to some extent.

Figure 10. Phylogeny of the lepidopteran species. Phylogenetic tree inferred from amino acid sequences of 13 PCGs of the mitogenome by using Neighbor Joining (NJ) and Maximum parsimony (MP). Numbers at each node indicate bootstrap support; percentages of NJ probabilities (first value) and MP bootstrap support values (second value), respectively. Drosophila melanogaster [47] and Locusta migratoria manilensis were used as outgroup.

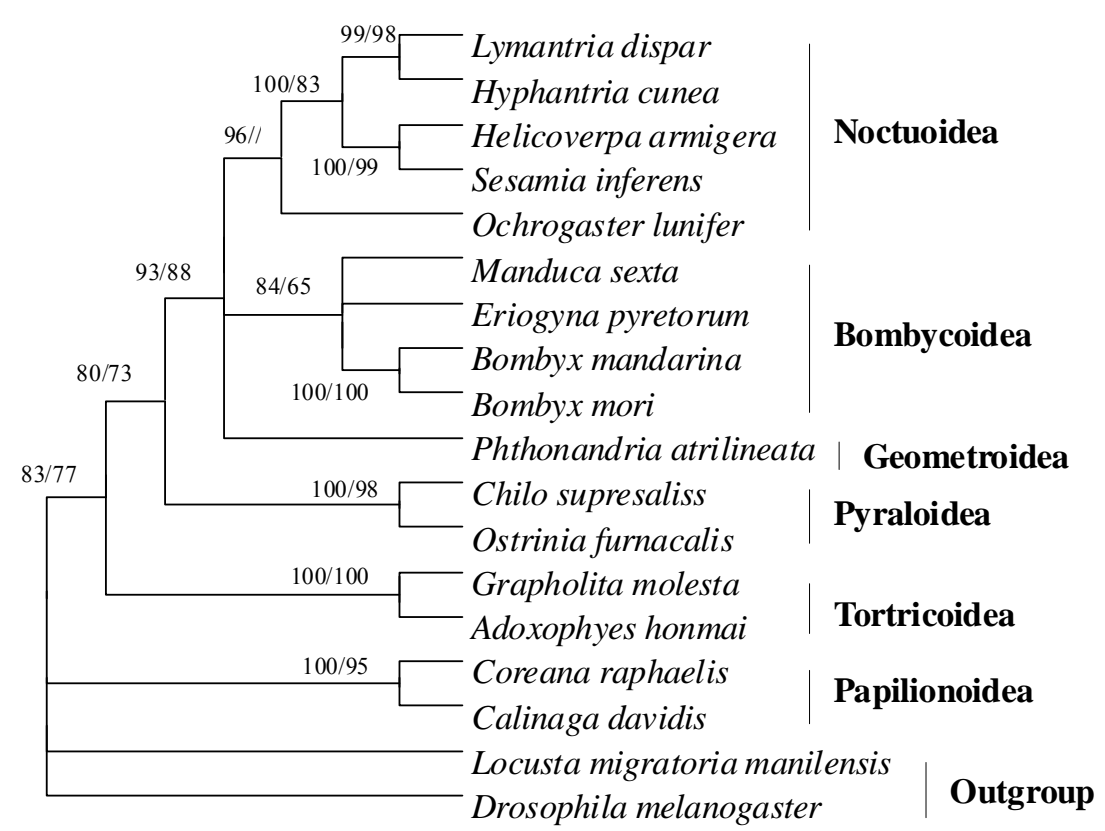




\section{Experimental Section}

\subsection{DNA Extraction}

Adult $S$. inferens were collected from rice paddies surrounding Yangzhou $\left(32^{\circ} 40.025 \mathrm{~N}, 119^{\circ} 44.017 \mathrm{E}\right)$, Jiangsu Province, China. Samples were preserved in $100 \%$ ethanol and stored at $-70{ }^{\circ} \mathrm{C}$ until DNA extraction was performed. Whole genomic DNA was extracted from a single sample using the protocol of DNAVzol (Bioteke, Beijing, China) and then used for the PCR amplification.

\subsection{Primers Design, PCR Amplification, Cloning and Sequencing}

Two pairs of LA-PCR primers were used for amplification of two overlapping fragments of S. inferens mitogenome, which were 16SAA (5'-ATGCTWCCTTTGCACRGTCAAGATACYGCG GC-3'), 16SBB (5'-CTTATCGAYAAAAAAGWTTGCGACCTCRATGTTG-3'), LP01 (5'-TGATTAG CTCCACAAATTTCTGAACATTGACC-3'), and LP02 (5'-WACACCAGTTCATATTDAACCAGA ATGATATT-3') [48]. Sub-PCR primers were designed from comparisons of 35 lepidopteran sequences available in GenBank and referenced to the universal primers of insect mitogenomes [49].

The conditions for amplification of two long fragments were as follows: An initial denaturation for 2 min at $96^{\circ} \mathrm{C}$ followed by 35 cycles of $10 \mathrm{~s}$ at $98^{\circ} \mathrm{C}, 10 \mathrm{~min}$ at $58{ }^{\circ} \mathrm{C}$, and a subsequent 10 min final extension at $72{ }^{\circ} \mathrm{C}$. PCR conditions for amplification of other fragments were as follows: An initial denaturation for $5 \mathrm{~min}$ at $95{ }^{\circ} \mathrm{C}$, followed by 35 cycles of denaturation for $1 \mathrm{~min}$ at $94{ }^{\circ} \mathrm{C}$, annealing for $1 \mathrm{~min}$ at $45-50{ }^{\circ} \mathrm{C}$, elongation for $1-3 \mathrm{~min}$ (depending on putative length of the fragments) at $68^{\circ} \mathrm{C}$, and a final extension step of $72^{\circ} \mathrm{C}$ for $10 \mathrm{~min}$. For most fragments, LA Taq polymerase (TaKaRa, Kyoto, Japan) was used for the PCR amplification, but for fragments less than $1.3 \mathrm{~kb}$, LA Taq polymerase was replaced by Taq polymerase (TaKaRa, Kyoto, Japan) in the PCR reaction. All PCR reactions were performed in an ABI thermal cycler (PE Applied Biosystems, CA, USA).

PCR products were separated by electrophoresis in a $1.0 \%$ agarose gel and purified using a DNA Gel Extraction Kit (Bioteke, Beijing, China). Purified PCR products were ligated into the T-vector (TaKaRa, Kyoto, Japan) and then transformed into XL-1 blue competent bacteria, according to the method of Wei et al. [50]. The positive recombinant clone was sequenced using upstream and downstream primers from bi-directions on ABI 3730XL Automated DNA Sequencer (PE Applied Biosystems, CA, USA) at least three times.

\subsection{Sequence Analysis}

The Staden package was used for sequence assembly and annotation [51]. The PCGs and rRNA genes in $S$. inferens mitogenome were identified by sequence alignment with other lepidopteran species, especially the Noctuidae by using Clustal X version 2.0 [4-7,52]. The PCG nucleotide sequences without start and termination codons were translated on the basis of the Invertebrate Mitochondrial Genetic Code. The AT content was calculated using MEGA version 5.0 [35]. Composition skew analysis was carried out with formulas AT skew $=[\mathrm{A}-\mathrm{T}] /[\mathrm{A}+\mathrm{T}]$ and $\mathrm{GC}$ skew $=[\mathrm{G}-\mathrm{C}] /[\mathrm{G}+\mathrm{C}][53]$.

Transfer RNA genes were identified using tRNAscan-SE software available online [54], and the software of XRNA $1.2 .0 \mathrm{~b}$ was used to draw the secondary structure of RNA genes. The secondary 
structures of the $r r n L$ and $r r n S$ genes were inferred based on models developed for other insect species [27,55]. To infer the rRNA gene secondary structures, we used a commonly accepted comparative approach to correct for unusual pairings with RNA-editing mechanisms that are well known in arthropod mitogenomes [56,57]. The entire A+T-rich region was subjected to a search for tandem repeats using the Tandem Repeats Finder program [58].

\subsection{Phylogenetic Analysis}

To illustrate the phylogenetic relationship of Lepidoptera, the other sixteen complete lepidopteran mitogenomes were downloaded from Genbank, including A. honmai (DQ073916), B. mori (AY048187), B. mandarina (FJ384796), C. davidis (HQ658143), C. raphaelis (DQ102703), C. suppressalis (JF339041), E. pyretorum (FJ685653), G. molesta (HQ392511), H. armigera (GU188273), H. cunea (GU592049), L. dispar (FJ617240), M. sexta (EU286785), O. furnacalis (AF467260), O. lunifer (AM946601), P. atrilineata (EU569764), Drosophila melanogaster (U37541) and Locusta migratoria manilensis (GU344101) were used as outgroup.

The alignment of the concatenated amino acid sequences of each 13 mitochondrial PCGs was aligned with Clustal X [52] using default settings. Then, based on the concatenated amino acid data set from the 13 PCGs, phylogenetic analyses were constructed using MEGA version 5.0 software with Neighbor Joining (NJ) and Maximum Parsimony (MP) methods [35]. Bootstrap analysis was done with 1000 replications, and bootstrap values were calculated using the $50 \%$ majority rule.

\section{Conclusions}

In the present study, the mitogenome for S. inferens was one of five sequenced mitogenomes of the Noctuidae species, which includes about $10 \%$ of all recorded lepidopteran species. Compared to four other noctuid moths, the newly determined mitogenome also shared the gene order, nucleotide composition of protein-coding genes, the presence of intergenic spacers, and other features [4-7]. The order of trnM, trnI, and trnQ in the mitogenome might be one of the features that characterize the whole order Lepidoptera. The S. inferens mitogenome was biased to use T rather than A, which was different from other noctuid moths. The s4 spacer did not contain the motif "ATACTAA" that was one potential characteristic feature conserved across four other noctuid moths, the reason may be related to genetic mutation [59]. The great difference was that the stem-and-loop structure was found in the A+T-rich region of $S$. inferens mitogenome, but it was not observed in the four other noctuid moths. Although the $S$. inferens mitogenome was added, the position of Noctuidae is not improved. More insect mitogenomes will be helpful to fully resolve the phylogeny of Noctuoidea.

\section{Acknowledgements}

We thank Guo (Harvard University) for improving the text of the manuscript. This work was supported by the Special Fund for the National Basic Research and Development Program (973) of China (No. 2012CB114100). 


\section{References}

1. Savary, S.; Willocquet, L.; Elazegui, F.S.; Castilla, N.P.; Teng, P.S. Rice pest constraints in tropical Asia: Quantification of yield losses due to rice pests in a range of production situations. Plant Dis. 2000, 84, 357-369.

2. Singh, J.; Shera, P.S. Relative abundance of different species of rice stem borers in punjab, India. Presented at the national conference on plant protection-New horizons in the millennium. rajasthan college of agriculture, Udaipur, India, 2001.

3. Sheng, C.F.; Wang, H.T.; Sheng, S.Y.; Gao, L.D.; Xuan, W.J. Pest status and loss assessment of crop damage caused by the rice borers, Chilo suppressalis and Tryporyza incertulas in China. Entomol. Knowl. 2003, 40, 289-294.

4. Salvato, P.; Simonato, M.; Battisti, A.; Negrisolo, E. The complete mitochondrial genome of the bag-shelter moth Ochrogaster lunifer (Lepidoptera, Notodontidae). BMC Genomics 2008, 9, doi:10.1186/1471-2164-9-331.

5. Liao, F.; Wang, L.; Wu, S.; Li, Y.P.; Zhao, L.; Huang, G.M.; Niu, C.J.; Liu, Y.Q.; Li, M.G. The complete mitochondrial genome of the fall webworm, Hyphantria cunea (Lepidoptera: Arctiidae). Int. J. Biol. Sci. 2010, 6, 172-186.

6. Yin. J.; Hong, G.Y.; Wang, A.M.; Cao, Y.Z.; Wei, Z.J. Mitochondrial genome of the cotton bollworm Helicoverpa armigera (Lepidoptera: Noctuidae) and comparison with other Lepidopterans. Mitochondrial DNA 2010, 21, 160-169.

7. Zhu, Y.J.; Zhou, G.L.; Fang, R.; Ye, J.; Yi, J.P. The complete sequence determination and analysis of Lymantria dispar (Lepidoptera: Lymantriidae) mitochondrial genome. Plant Quar. 2010, 4, $6-11$.

8. Wolstenholme, D.R. Animal mitochondrial DNA: Structure and evolution. Int. Rev. Cytol. 1992, $141,173-216$.

9. Boore, J.L. Animal mitochondrial genomes. Nucleic Acids Res. 1999, 27, 1726-1780.

10. Da Silva, N.M.; de Souza Dias, A.; da Silva Valente, V.L.; Victor, H.V. Characterization of mitochondrial control region, two intergenic spacers and tRNAs of Zaprionus indianus (Diptera: Drosophilidae). Genetica 2009, 137, 325-332.

11. Wei, S.J.; Shi, M.; He, J.H.; Sharkey, M.J.; Achterberg, C.V.; Chen, X.X. Comparative mitogenomics of Braconidae (Insecta: Hymenoptera) and the phylogenetic utility of mitochondrial genomes with special reference to Holometabolous insects. BMC Genomics 2010, 11, doi:10.1186/1471-2164-11-371.

12. Cameron, S.L.; Yoshizawa, K.; Mizukoshi, A.; Whiting, M.F.; Johnson, K.P. Mitochondrial genome deletions and minicircles are common in lice (Insecta: Phthiraptera). BMC Genomics 2011, 12, doi:10.1186/1471-2164-12-394.

13. Anderson, S.; Bankier, A.T.; Barrell, B.G.; de Bruijn, M.H.; Coulson, A.R.; Drouin, J.; Eperon, I.C.; Nierlich, D.P.; Roe, B.A.; Sanger, F.; et al. Sequence and organization of the human mitochondrial genome. Nature 1981, 290, 457-465.

14. Boore, J.L.; Lavrov, D.; Brown, W.M. Gene translocation links insects and crustaceans. Nature 1998, 393, 667-668. 
15. Kim, I.; Lee, E.M.; Seol, K.Y.; Yun, E.Y.; Lee, Y.B.; Hwang, J.S.; Jin, B.R. The mitochondrial genome of the Korean hairsteak, Coreana raphaelis (Lepidoptera: Lycaenidae). Insect Mol. Biol. 2006, 15, 217-225.

16. Gong, Y.J.; Shi, B.C.; Kang, Z.J.; Zhang, F.; Wei, S.J. The complete mitochondrial genome of the oriental fruit moth Grapholita molesta (Busck) (Lepidoptera: Tortricidae). Mol. Biol. Rep. 2012, 39, 2893-2900.

17. De Bruijn, M.H. Drosophila melanogaster mitochondrial DNA, a novel organization and genetic code. Nature 1983, 304, 234-241.

18. Beard, C.B.; Hamm, D.M.; Collins, F.H. The mitochondrial genome of the mosquito Anopheles gambiae: DNA sequence, genome organization, and comparisons with mitochondrial sequences of other insects. Insect Mol. Biol. 1993, 2, 103-124.

19. Junqueira, A.C.; Lessinger, A.C.; Torres, T.T.; da Silva, F.R.; Vettore, A.L.; Arruda, P.; Azeredo Espin, A.M. The mitochondrial genome of the blowfly Chrysomya chloropyga (Diptera: Calliphoridae). Gene 2004, 339, 7-15.

20. Krzywinski, J.; Grushko, O.G.; Besansky, N.J. Analysis of the complete mitochondrial DNA from Anopheles funestus: An improved dipteran mitochondrial genome annotation and a temporal dimension of mosquito evolution. Mol. Phylogenet. Evol. 2006, 39, 417-423.

21. Masta, S.E.; Boore, J.L. The complete mitochondrial genome sequence of the spider Habronattus oregonensis reveals rearranged and extremely truncated tRNAs. Mol. Biol. Evol. 2004, 21, 893-902.

22. Crozier, R.H.; Crozier, Y.C. The mitochondrial genome of the honeybee Apis mellifera: Complete sequence and genome organization. Genetics 1993, 133, 97-117.

23. Xia, X. Maximizing transcription efficiency causes codon usage bias. Genetics 1996, 144, 1309-1320.

24. Shao, R.F.; Barker, S.C. The highly rearranged mitochondrial genome of the plague thrips, Thrips imaginis (Insecta: Thysanoptera): Convergence of two novel gene boundaries and an extraordinary arrangement of rRNA genes. Mol. Biol. Evol. 2003, 20, 362-370.

25. Yamauchi, M.M.; Miya, M.U.; Nishida, M. Complete mitochondrial DNA sequence of the swimming crab, Portunus trituberculatus (Crustacea: Decapoda: Brachyura). Gene 2003, 311, 129-135.

26. Gutell, R.R.; Lee, J.C.; Cannone, J.J. The accuracy of ribosomal RNA comparative structure models. Curr. Opin. Struct. Biol. 2002, 12, 301-310.

27. Gillespie, J.J.; Johnston, J.S.; Cannone, J.J.; Gutell, R.R. Characteristics of the nuclear (18S, 5.8S, $28 \mathrm{~S}$ and $5 \mathrm{~S}$ ) and mitochondrial (12S and 16S) rRNA genes of Apis mellifera (Insecta: Hymenoptera): Structure, organization, and retrotransposable elements. Insect Mol. Biol. 2006, 15, 657-686.

28. Cameron, S.L.; Whiting, M.F. The complete mitochondrial genome of the tobacco hornworm, Manduca sexta (Insecta: Lepidoptera: Sphingidae), and an examination of mitochondrial gene variability within butterflies and moths. Gene 2008, 408, 112-123. 
29. Chai, H.N.; Du, Y.Z.; Zhai, B.P. Characterization of the complete mitochondrial genomes of Cnaphalocrocis medinalis and Chilo suppressalis (Lepidoptera: Pyralidae). Int. J. Biol. Sci. 2012, 8, 561-579.

30. Zhang, D.X.; Hewitt, G.M. Insect mitochondrial control region: A review of its structure, evolution and usefulness in evolutionary studies. Biochem. Syst. Ecol. 1997, 25, 99-120.

31. Clary, D.O.; Wolstenholme, D.R. Drosophila mitochondrial DNA: Conserved sequences in the A+T-rich region and supporting evidence for a secondary structure model of the small ribosomal RNA. J. Mol. Evol. 1987, 25, 116-125.

32. Zhang, D.; Szymura, J.M.; Hewitt, G.M. Evolution and structural conservation of the control region of insect mitochondrial DNA. J. Mol. Evol. 1995, 40, 382-391.

33. Rand, D.M.; Harrison, R.G. Molecular population genetics of mtDNA size variation in crickets. Genetics 1989, 121, 551-569.

34. Schultheis, A.S.; Weigt, L.A.; Hendricks, A.C. Arrangement and structural conservation of the mitochondrial control region of two species of Plecoptera: Utility of tandem repeat-containing regions in studies of population genetics and evolutionary history. Insect Mol. Biol. 2002, 11, 605-610.

35. Hong, M.Y.; Lee, E.M.; Jo, Y.H.; Park, H.C.; Kim, S.R.; Hwang, J.S.; Jin, B.R.; Kang, P.D.; Kim, K.G.; Han, Y.S.; Kim, I. Complete nucleotide sequence and organization of the mitogenome of the silk moth Caligula boisduvalii (Lepidoptera: Saturniidae) and comparison with other lepidopteran insects. Gene 2008, 413, 49-57.

36. Kim, S.R.; Kim, M.I.; Hong, M.Y.; Kim, K.Y.; Kang, P.D.; Hwang, J.S.; Han, Y.S.; Jin, B.R.; Kim, I. The complete mitogenome sequence of the Japanese oak silkmoth, Antheraea yamamai (Lepidoptera: Saturniidae). Mol. Biol. Rep. 2009, 36, 1871-1880.

37. Kim, I.; Cha, S.Y.; Yoon, M.H.; Hwang, J.S.; Lee, S.M.; Sohn, H.D.; Jin, B. The complete nucleotide sequence and gene organization of the mitochondrial genome of the oriental mole cricket, Gryllotalpa orientalis (Orthoptera: Gryllotalpidae). Gene 2005, 353, 155-168.

38. Lee, E.S.; Shin, K.S.; Kim, M.S.; Park, H.; Cho, S.; Kim, C.B. The mitochondrial genome of the smaller tea tortrix Adoxophyes honmai (Lepidoptera: Tortricidae). Gene 2006, 373, 52-57.

39. Hassanin, A. Phylogeny of Arthropoda inferred from mitochondrial sequences: Strategies for limiting the misleading effects of multiple changes in pattern and rates of substitution. Mol. Phylogenet. Evol. 2006, 38, 100-116.

40. Kristensen, N.P.; Skalski, A.W. Phylogeny and Paleontology. In Lepidoptera: Moths and Butterflies. 1. Evolution, Systematics, and Biogeography. Handbook of Zoology; Kristensen, N.P., Ed.; De Gruyter: Berlin, Germany and New York, NY, USA, 1999; Volume IV, Part 35, pp. 7-25.

41. Yang, L.; Wei, Z.J.; Hong, G.Y.; Jiang, S.T.; Wen, L.P. The complete nucleotide sequence of the mitochondrial genome of Phthonandria atrilineata (Lepidoptera: Geometridae). Mol. Biol. Rep. 2009, 36, 1441-1449.

42. Hu, X.L.; Cao, G.L.; Xue, R.Y.; Zheng, X.J.; Zhang, X.; Duan, H.R.; Gong, C.L. The complete mitogenome and phylogenetic analysis of Bombyx mandarina strain Qingzhou. Mol. Biol. Rep. 2010, 37, 2599-2608. 
43. Lu, C.; Liu, Y.Q.; Liao, X.S.; Li, B.; Xiang, Z.X.; Han, H.; Wang, X.G. Complete sequence determination and analysis of Bombyx mori mitochondrial genome. J. Agric. Biotechnol. 2002, 10, 163-170.

44. Jiang, S.T.; Hong, G.Y.; Yu, M.; Li, N.; Yang, Y.; Liu, Y.Q.; Wei, Z.J. Characterization of the complete mitochondrial genome of the giant silkworm moth, Eriogyna pyretorum (Lepidoptera: Saturniidae). Int. J. Biol. Sci. 2009, 5, 351-365.

45. Xia, J.; Hu, J.; Zhu, G.P.; Zhu, C.D.; Hao, J.S. Sequencing and analysis of the complete mitochondrial genome of Calinaga davidis Oberthür (Lepidoptera: Nymphalidae). Acta Entomol. Sin. 2011, 54, 555-565.

46. Coates, B.S.; Sumerford, D.V.; Hellmich, R.L.; Lewis, L.C. Partial mitochondrial genome sequences of Ostrinia nubilalis and Ostrinia furnicalis. Int. J. Biol. Sci. 2005, 1, 13-18.

47. Lewis, D.L.; Farr, C.L.; Kaguni, L.S. Drosophila melanogaster mitochondrial DNA: Completion of the nucleotide sequence and evolutionary comparisons. Insect Mol. Biol. 1995, 4, 263-278.

48. Hwang, U.W.; Park, C.J.; Yong, T.S.; Kim, W. One-step PCR amplification of complete arthropod mitochondrial genomes. Mol. Phylogenet. Evol. 2001, 19, 345-352.

49. Simon, C.; Frati, F.; Beckenbach, A.T.; Crespi, B.; Liu, H.; Flook, P. Evolution, weighting and phylogenetics utility of mitochondrial gene sequences and compilation of conserved polymerase chain reaction primers. Ann. Entomol. Soc. Am. 1994, 87, 651-701.

50. Wei, Z.J.; Hong, G.Y.; Jiang, S.T.; Tong, Z.X.; Lu, C. Characters and expression of the gene encoding DH, PBAN and other FXPRLamide family neuropeptides in Antheraea pernyi. J. Appl. Entomol. 2008, 132, 59-67.

51. Staden Package. Available online: http://staden.sourceforge.net (accessed on 5 December 2011).

52. Larkin, M.A.; Blackshields, G.; Brown, N.P.; Chenna, R.; McGettigan, P.A.; McWilliam, H.; Valentin, F.; Wallace, I.M.; Wilm, A.; Lopez, R. Clustal W and Clustal X version 2.0. Bioinformatics 2007, 23, 2947-2948.

53. Perna, N.T.; Kocher, T.D. Patterns of nucleotide composition at fourfold degenerate sites of animal mitochondrial genomes. J. Mol. Evol. 1995, 41, 353-358.

54. Lowe, T.M.; Eddy, S.R. tRNAscan-SE: A program for improved detection of transfer RNA genes in genomic sequence. Nucleic Acids Res. 1997, 25, 955-964.

55. Cannone, J.J.; Subramanian, S.; Schnare, M.N.; Collett, J.R.; D’Souza, L.M.; Du, Y.; Feng, B.; Lin, N.; Madabusi, L.V.; Müller, K.M.; et al. The comparative RNA web (CRW) site: An online database of comparative sequence and structure information for ribosomal, intron, and other RNAs. BMC Bioinform. 2002, 3, doi:10.1186/1471-2105-3-15.

56. Gutell, R.R.; Larsen, N.; Woese, C.R. Lessons from an evolving rRNA: 16S and 23S rRNA structures from a comparative perspective. Microbiol. Rev. 1994, 58, 10-26.

57. Buckley, T.R.; Simon, C.; Flook, P.K.; Misof, B. Secondary structure and conserved motifs of the frequently sequenced domains IV and $\mathrm{V}$ of the insect mitochondrial large subunit rRNA gene. Insect Mol. Biol. 2000, 9, 565-580.

58. Benson, G. Tandem repeats finder: A program to analyze DNA sequences. Nucleic Acids Res. 1999, 27, 573-580. 
59. Bachtrog, D. Reduced selection for codon usage bias in Drosophila Miranda. J. Mol. Evol. 2007, 64, 586-590.

(C) 2012 by the authors; licensee MDPI, Basel, Switzerland. This article is an open access article distributed under the terms and conditions of the Creative Commons Attribution license (http://creativecommons.org/licenses/by/3.0/). 